\title{
On the competition among aerosol number, size and composition in predicting CCN variability: a multi-annual field study in an urbanized desert
}

\author{
E. Crosbie ${ }^{1}$, J.-S. Youn ${ }^{2}$, B. Balch ${ }^{3}$, A. Wonaschütz ${ }^{4}$, T. Shingler ${ }^{3}$, Z. Wang $^{3}$, W. C. Conant ${ }^{1}$, E. A. Betterton ${ }^{1}$, and \\ A. Sorooshian ${ }^{3,1,2}$ \\ ${ }^{1}$ Department of Atmospheric Sciences, University of Arizona, Tucson, AZ, USA \\ ${ }^{2} \mathrm{Mel}$ and Enid Zuckerman College of Public Health, University of Arizona, Tucson, AZ, USA \\ ${ }^{3}$ Department of Chemical and Environmental Engineering, University of Arizona, Tucson, AZ, USA \\ ${ }^{4}$ University of Vienna, Faculty of Physics, Vienna, Austria
}

Correspondence to: A. Sorooshian (armin@email.arizona.edu)

Received: 10 December 2014 - Published in Atmos. Chem. Phys. Discuss.: 10 February 2015

Revised: 10 June 2015 - Accepted: 11 June 2015 - Published: 25 June 2015

\begin{abstract}
A 2-year data set of measured CCN (cloud condensation nuclei) concentrations at $0.2 \%$ supersaturation is combined with aerosol size distribution and aerosol composition data to probe the effects of aerosol number concentrations, size distribution and composition on $\mathrm{CCN}$ patterns. Data were collected over a period of 2 years (2012-2014) in central Tucson, Arizona: a significant urban area surrounded by a sparsely populated desert. Average $\mathrm{CCN}$ concentrations are typically lowest in spring $\left(233 \mathrm{~cm}^{-3}\right)$, highest in winter $\left(430 \mathrm{~cm}^{-3}\right)$ and have a secondary peak during the North American monsoon season (July to September; $372 \mathrm{~cm}^{-3}$ ). There is significant variability outside of seasonal patterns, with extreme concentrations ( 1 and $99 \%$ levels) ranging from 56 to $1945 \mathrm{~cm}^{-3}$ as measured during the winter, the season with highest variability.

Modeled CCN concentrations based on fixed chemical composition achieve better closure in winter, with size and number alone able to predict $82 \%$ of the variance in $\mathrm{CCN}$ concentration. Changes in aerosol chemical composition are typically aligned with changes in size and aerosol number, such that hygroscopicity can be parameterized even though it is still variable. In summer, models based on fixed chemical composition explain at best only $41 \%$ (pre-monsoon) and $36 \%$ (monsoon) of the variance. This is attributed to the effects of secondary organic aerosol (SOA) production, the competition between new particle formation and condensational growth, the complex interaction of meteorology, regional and local emissions and multi-phase chemistry dur-
\end{abstract}

ing the North American monsoon. Chemical composition is found to be an important factor for improving predictability in spring and on longer timescales in winter.

Parameterized models typically exhibit improved predictive skill when there are strong relationships between CCN concentrations and the prevailing meteorology and dominant aerosol physicochemical processes, suggesting that similar findings could be possible in other locations with comparable climates and geography.

\section{Introduction}

The influence of atmospheric aerosol particles on cloud properties and the consequential changes in radiative forcing carry the largest source of uncertainty in climate change prediction (IPCC, 2013). Cloud condensation nuclei (CCN) are the subset of aerosol particles that activate into droplets at a given supersaturation and their concentration therefore contributes to governing the microphysical and optical properties of clouds (Twomey, 1977; Albrecht, 1989). The global, spatial and temporal variability of CCN concentrations consequently hold significant weight in predicting the droplet distribution in clouds and the ensuing microphysical and radiative properties (McFiggans et al., 2006; Andreae and Rosenfeld, 2008). Ultimately, CCN have been found to be a major factor in modulating cloud dynamics in both clean and 
polluted environments, with direct consequences on the hydrological cycle (Andreae et al., 2004; Altaratz et al., 2008; Stevens and Feingold, 2009).

While laboratory experiments involving the activation of single salt species (e.g., ammonium sulfate) or simple mixtures of organic compounds have offered satisfactory experimental validation (e.g., Brechtel and Kreidenweis, 2000) of the original underlying physical theory of droplet activation (Köhler, 1936), the extension to ambient atmospheric aerosol has proven more elusive (Covert et al., 1998; Chuang et al., 2000; Roberts et al., 2002; McFiggans et al., 2006; Ervens et al., 2010). Recent field studies (e.g., Broekhuizen et al., 2006; Dusek et al., 2006; Ervens et al., 2007; Hudson, 2007; Cubison et al., 2008; Quinn et al., 2008; Ervens et al., 2010; Burkart et al., 2011), spanning a range of aerosol scenarios, have not yet provided a comprehensive agreement on the relative importance of factors which affect $\mathrm{CCN}$ and the cloud droplet number, namely the following: the aerosol number, size distribution, composition, supersaturation and aerosol mixing state (Lance et al., 2004; Rissman et al., 2004; McFiggans et al., 2006; Andreae and Rosenfeld, 2008; Partridge et al., 2012).

During cloud formation, the supersaturation is driven by a combination of aerosol-related properties and dynamics (i.e., the updraft velocity) and therefore a complete description of the cloud system involves a two-way coupling of aerosol microphysics with circulation dynamics (Feingold, 2003). Modeling studies have shown that typically, the supersaturation adjusts to large changes in aerosol properties (i.e., number, size and composition) to dampen the resulting variability observed in cloud droplet number concentration (Feingold, 2003); however, it has also been found that the distribution of CCN can have a significant impact on the cloud microphysics by affecting the droplet distribution (Feingold et al., 1999; McFiggans et al., 2006). The dynamics of initial droplet growth is affected by CCN properties (Feingold and Chuang, 2002; Raymond and Pandis, 2002, 2003; Chuang, 2003) and interstitial gas chemistry (Nenes et al., 2002; Lim et al., 2005), affecting gas-particle partitioning through cloud processing.

Excluding the environmental factors that regulate supersaturation and droplet growth kinetics and focusing only on aerosol-related properties that drive the initial activation, yields important information relating to hygroscopicity. CCN closure studies typically attempt to model the CCN concentration from measured aerosol number, size and composition and then compare the modeled CCN to direct measurements under a controlled set of supersaturated conditions (e.g., Dusek et al., 2006; Ervens et al., 2007; Cubison et al., 2008; Bougiatioti et al., 2009; Lance et al., 2009; Ervens et al., 2010; Jurányi et al., 2011; Martin et al., 2011; Levin et al., 2012; Moore et al., 2012; Lathem et al., 2013; Wu et al., 2013; Almeida et al., 2014). The respective importance of composition and size distribution on $\mathrm{CCN}$ activation remains an outstanding question. Closure studies have gener- ally been successful for background and remote sites (e.g., Jurányi et al., 2010), but less so in urban areas (e.g., Burkart et al., 2012). The complexity of the aerosol composition and variability in the aerosol mixing state are often the explanation for unsatisfactory closure, under assumptions of bulk hygroscopic properties (Cubison et al., 2008; Ervens et al., 2010). The single hygroscopicity parameter $\kappa$-Köhler theory (Petters and Kreidenweis, 2007, 2008) provides a theoretical framework to derive bulk hygroscopicity for internal mixtures, based on a volume-weighted mixing rule. While this simplicity is advantageous for closure models, this approach may not be suitable for particles with complex morphology (e.g., Dusek et al., 2011; Hersey et al., 2013).

Physical aging processes such as coagulation and condensational growth tend to shift the aerosol population towards a more uniform mixing state, when compared to fresh emissions (Covert and Heintzenberg, 1993; Ervens et al., 2010). While condensational growth processes increase CCN concentration by growing ultrafine particles into the critical range for droplet activation, coagulation may result in either increasing or decreasing $\mathrm{CCN}$ concentration since increased size comes at the expense of aerosol number (Riipinen et al., 2011). Uncertainties in nucleation rates and primary emissions have been shown to have significant impacts on global estimates of CCN concentration (Pierce and Adams, 2009).

The study of CCN activation within an urban environment offers unique opportunities to address the challenges associated with the inhomogeneity of sources and aerosol aging, which gives rise to difficulties in predicting water uptake behavior. Field studies purporting to quantify the influences of aerosol number, size and compositional factors on CCN activity are often carried out over a limited, but intense period and hence offer a worthy characterization of the duration of the study but perhaps lack climatological context, even related to sub-seasonal variability. The current study addresses the two aforementioned issues by reporting on longterm measurements of $\mathrm{CCN}$, submicron size distributions and composition taken jointly over multiple years in an urban area, specifically Tucson, Arizona.

Tucson is located in the heart of the Sonoran Desert in the semi-arid southwestern United States. This location offers some unique opportunities for the study of CCN activation, primarily since there have been comparatively fewer documented measurements of $\mathrm{CCN}$ in arid regions. In addition, southern Arizona is situated in the region affected by the North American monsoon (NAM) and as a result, the highest monthly rainfall occurs during July and August and is accompanied by a strong influx of tropical moisture. The onset of the NAM in late June or early July leads to a rapid change from very hot and dry pre-monsoon conditions to the humid conditions associated with the monsoon and leads to changes in the aerosol properties (Sorooshian et al., 2011; Youn et al., 2013). Aside from the NAM, southern Arizona is situated in a relatively stable synoptic weather pattern, which gives rise to generally clear skies and light surface winds. 
The strong insolation produces a deep convective boundary layer in the afternoon, and clear conditions lead to significant nocturnal cooling, which together produce a significant but predictable diurnal cycle in temperature, humidity and convective boundary-layer mixing.

The paper is subdivided as follows: (i) experimental methods and data collection are provided in Sect. 2; (ii) an overview of the "climatological" results is given in Sect. 3; (iii) the influence of size distribution and its relationship with composition is discussed in Sect. 4; (iv) CCN closure analysis is presented in Sect. 5 and (v) conclusions are presented in Sect. 6.

\section{Data and methods}

\subsection{Tucson Aerosol Characterization Observatory (TACO)}

The study site is located at a rooftop location (approximately $30 \mathrm{~m}$ above ground) on the University of Arizona campus $\left(32.2299^{\circ} \mathrm{N}, 110.9538^{\circ} \mathrm{W} ; 720 \mathrm{~m}\right.$ a.s.l.) in central Tucson (metro population $\sim 1$ million; U.S. Census Bureau, 2011). The sample inlet was located at rooftop level, approximately at the same height as nearby buildings, and $2 \mathrm{~km}$ northeast of downtown Tucson. The study period spanned more than 2 years (April 2012-August 2014) and comprised long-term continuous measurements of $\mathrm{CCN}$ and related quantities, with a constant experimental setup.

\subsection{Aerosol instrumentation}

Bulk CCN concentrations were measured using a $\mathrm{CCN}$ counter at fixed $0.2 \%$ supersaturation $(\mathrm{CCN}-100$ Droplet Measurement Technologies; Roberts and Nenes, 2005). Particle size-resolved number concentrations were obtained using a scanning mobility particle sizer (SMPS 3080, TSI Inc.) coupled to a condensation particle counter (CPC 3772, TSI Inc.). The SMPS operated at $10: 1$ sheath-to-sample flow ratio and with a mobility diameter range from 13 to $748 \mathrm{~nm}$. The integration of the size-resolved data over the entire range provided a measure of total condensation nuclei $(\mathrm{CN})$. The $\mathrm{CCN}$ counter was calibrated twice during the study period using the method described in Rose et al. (2008) and exhibited a supersaturation of $0.192 \pm 0.005 \%$ at the nominal $0.2 \%$ set-point value. A semi-continuous OC / EC analyzer (Sunset Laboratories Inc.) measured hourly organic carbon (OC) and elemental carbon (EC) concentrations in $\mathrm{PM}_{2.5}$. Limits of detection were 0.2 and $1.0 \mu \mathrm{g} \mathrm{m}^{-3}$ for EC and OC, respectively. Water-soluble organic carbon (WSOC) was measured in $\mathrm{PM}_{2.5}$ using a particle-into-liquid sampler (PILS, Brechtel Manufacturing Inc.) coupled to a total organic carbon analyzer (TOC; Sievers model 800) (Sullivan et al., 2006; Duong et al., 2011; Wonaschütz et al., 2011). The overall measurement uncertainty associated with the reported
WSOC concentrations is estimated to be approximately $10 \%$ with a limit of detection of $0.1 \mu \mathrm{g} \mathrm{m}^{-3}$.

\subsection{Local meteorology}

Collocated measurements of basic meteorological variables (including temperature, pressure, humidity, wind speed, wind direction and rainfall) were obtained at $5 \mathrm{~s}$ time resolution and archived as $1 \mathrm{~min}$ and hourly averages. In addition, 1 min direct normal irradiance (DNI) was obtained from the NREL Observed Atmospheric and Solar Information System (OASIS; http://www.nrel.gov/midc/ua_oasis/) site on an adjacent building on the university campus. SuomiNet GPSderived precipitable water vapor (PW) (Ware et al., 2000) data were obtained from the University of Arizona SA46 site $\left(32.2298^{\circ} \mathrm{N}, 110.9539^{\circ} \mathrm{W}, 762 \mathrm{~m}\right.$ a.s.l.) resolved to $30 \mathrm{~min}$ mean estimates. Finally, radiosonde data from the nearby $\mathrm{Na}-$ tional Weather Service were obtained from twice-daily balloon launches at 04:00 and 16:00, local time.

\subsection{EPA IMPROVE}

$\mathrm{PM}_{2.5}$ aerosol composition measurements were obtained from two sites in the Interagency Monitoring of Protected Visual Environments (IMPROVE) network of filter samples (Malm et al., 1994). The Saguaro National Monument site $\left(32.1742^{\circ} \mathrm{N}, 110.7372^{\circ} \mathrm{W} ; 933 \mathrm{~m}\right.$ a.s.l.) is located within the foothills of the Rincon Mountains at the eastern extent of the Tucson metropolitan area and approximately $21 \mathrm{~km}$ east of TACO. The Saguaro West site $\left(32.2486^{\circ} \mathrm{N}\right.$, $111.2178^{\circ} \mathrm{W} ; 718 \mathrm{~m}$ a.s.l.) is located on the western side of the topographically less prominent Tucson Mountains, approximately $25 \mathrm{~km}$ west of TACO. At each site, $24 \mathrm{~h}$ filter samples are collected every 3 days. Data were obtained to coincide with as much of the study period as possible and were available up to December 2013 at the time of writing. Filter samples were analyzed for ions, metal and nonmetal elements, and carbon (elemental and organic). Details on the extraction and analysis methodology are provided extensively elsewhere (http://vista.cira.colostate.edu/ improve/Publications/IMPROVE_SOPs.htm). In addition to direct measurement, the IMPROVE network reports empirically derived concentrations relevant to atmospheric aerosol including fine soil, sea salt, ammonium sulfate and ammonium nitrate (Malm et al., 1994).

\subsection{Data organization and quality control}

All TACO data (CCN, SMPS, OC / EC and meteorology) are time-synchronized and archived as averages at hourly increments. Sub-hourly variability in both the $\mathrm{CCN}$ concentration and the aerosol size distribution is highly influenced by localized intermittent sources, atmospheric turbulence and measurement-related lags and noise. Since many of the metrics used in the interpretation of $\mathrm{CCN}$ variability involve ratios (or other non-linear functions) combining $\mathrm{CCN}$ and 
Table 1. Seasonal mean and extreme $\mathrm{CN}$ and $\mathrm{CCN}$ concentrations from hourly averaged data. Seasons are defined as follows: winter (W, DJF), spring (S, MA), pre-monsoon (PM, MJ), monsoon (M, JAS) and fall (F, ON).

\begin{tabular}{llrrrrr}
\hline & $\begin{array}{l}\text { Concentration } \\
\left(\mathrm{cm}^{-3}\right)\end{array}$ & W & S & PM & M & F \\
\hline \multirow{3}{*}{$\mathrm{CN}$} & Mean & 5189 & 4853 & 3872 & 4200 & 5200 \\
& Max (99\%) & 14406 & 13799 & 10869 & 11606 & 13682 \\
& Min (1\%) & 749 & 686 & 807 & 1070 & 853 \\
\hline \multirow{2}{*}{$\mathrm{CCN}_{\mathrm{SS}=0.2 \%} \%$} & 430 & 233 & 301 & 372 & 303 \\
& Mean & 1945 & 809 & 667 & 741 & 951 \\
& Max (99\%) & 56 & 59 & 101 & 100 & 81 \\
\hline
\end{tabular}

SMPS data, pre-filtering data to $1 \mathrm{~h}$ reduces extraneous influences caused by sub-hourly covariance. All meteorological fields (except PW and radiosonde data) were additionally archived at $1 \mathrm{~min}$ resolution. SMPS data from May and June 2013 are removed owing to sub-optimal data quality, resulting from an instrument malfunction.

\section{Climatological results}

\subsection{Monthly and seasonal statistics}

Monthly statistics of $\mathrm{CN}$ and $\mathrm{CCN}$ concentrations (henceforth referred to as $\mathrm{CN}$ and $\mathrm{CCN}$ ) illustrate different trends as $\mathrm{CN}$ reveals a more stable annual cycle with minor reduction towards a minimum in June (Fig. 1). CCN is more variable annually, and has two distinct peaks with a primary peak in December and a secondary peak in August. April has the lowest average $\mathrm{CCN}$ and also the lowest variability, as indicated by the interquartile range in Fig. 1 for both $\mathrm{CN}$ and $\mathrm{CCN}$. Conversely the interquartile range in $\mathrm{CN}$ for April is one of the highest, although in general, $\mathrm{CN}$ exhibits significant sub-monthly variability when compared to the mean annual trends. OC and EC mass concentrations (Fig. 1c) exhibit similar annual cycles, which suggests that aerosol related to urban combustion sources are ubiquitous; however, in summer the contribution is diluted by higher mixing heights (Fig. 1f). Seasonal temperature ( $T$; Fig. 1d), relative humidity (RH; Fig. 1e) and direct normal irradiance (DNI; Fig. 1f) illustrate the impact of the NAM on local meteorology, where strong increases in moisture are accompanied by slight temperature reductions and increased cloud cover.

Henceforth, data are grouped seasonally rather than monthly to analyze the annual cycle. Five seasons are defined to reflect the significant difference in meteorology between the pre-monsoon summer and the onset of the NAM. These are winter (W, DJF), spring (S, MA), pre-monsoon (PM, MJ), monsoon (M, JAS) and fall (F, ON). Table 1 provides a summary of seasonal $\mathrm{CN}$ and $\mathrm{CCN}$ statistics and includes only periods when both measurements are available. Winter and fall have the highest mean $\mathrm{CN}$ concentrations $\left(\sim 5200 \mathrm{~cm}^{-3}\right)$, while pre-monsoon has the lowest with a

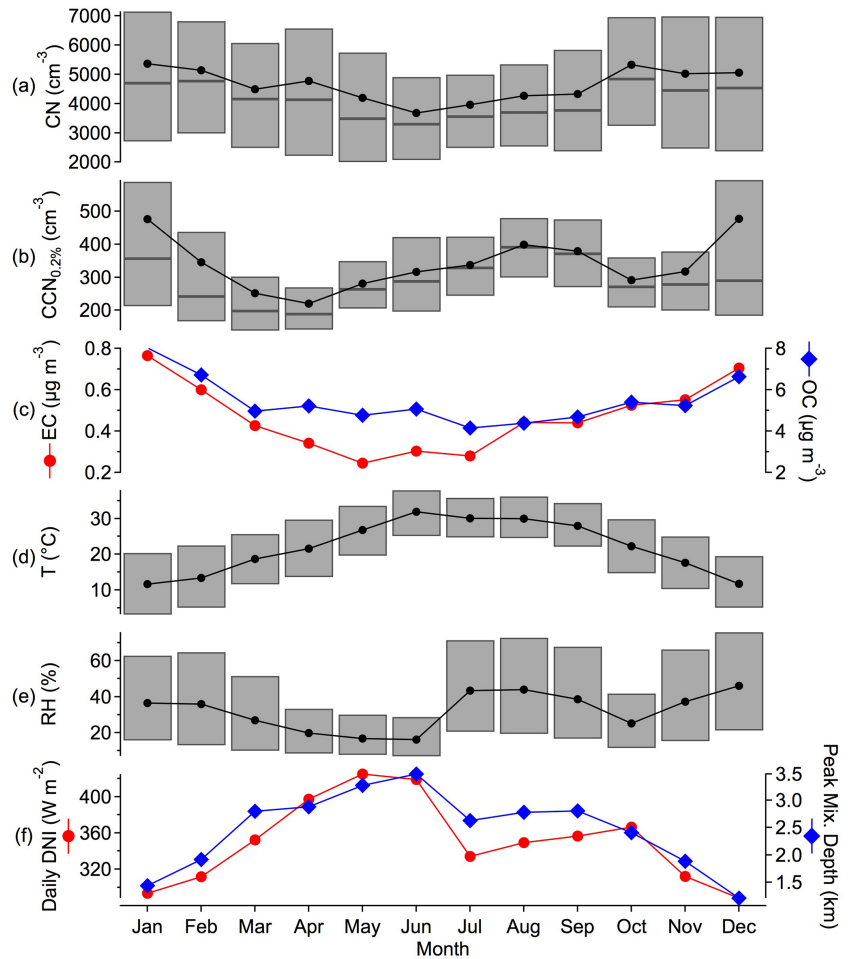

Figure 1. Monthly statistics of (a) $\mathrm{CN}$, (b) $\mathrm{CCN}(0.2 \%)$, (c) $\mathrm{OC}$ and EC, (d) temperature, (e) RH and (f) direct normal irradiance (DNI). Circles, diamonds and the lines connecting them represent monthly averages. For (a) $\mathrm{CN}$ and (b) $\mathrm{CCN}$, bars represent median and interquartile range of sub-monthly variability of the $1 \mathrm{~h}$ averaged data. For (d) temperature and (e) relative humidity, bars represent monthly extremes, as measured by 5 and $95 \%$ levels of the $1 \mathrm{~min}$ average data. DNI is presented using $24 \mathrm{~h}$ averages so that it includes the effect of the changing length of day with season, and peak mixing depth is calculated using the 16:00 radiosonde data.

mean just below $3900 \mathrm{~cm}^{-3}$. Extremes are quantified by 1 and $99 \%$ statistics and range between 749 and $14406 \mathrm{~cm}^{-3}$, with winter showing the highest variability. Average $\mathrm{CCN}$ concentrations are typically lowest in spring $\left(233 \mathrm{~cm}^{-3}\right)$, highest in winter $\left(430 \mathrm{~cm}^{-3}\right)$ and have a secondary peak during the monsoon $\left(372 \mathrm{~cm}^{-3}\right)$. Extremes in $\mathrm{CCN}$ range be- 


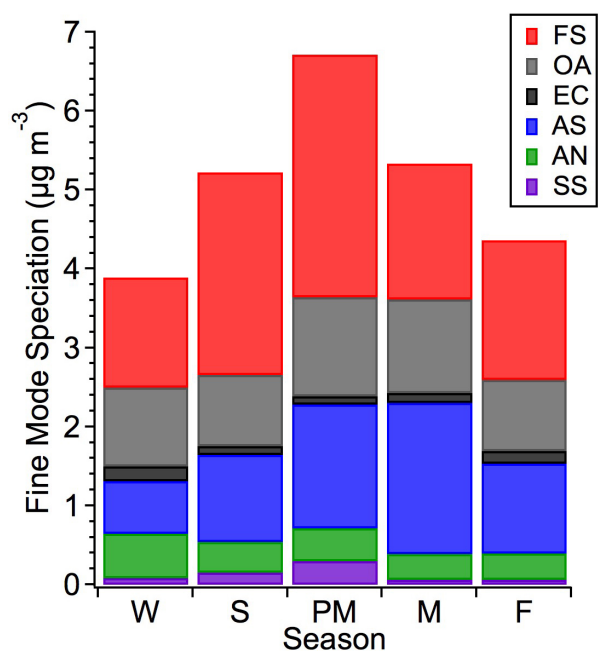

Figure 2. Seasonal $\mathrm{PM}_{2.5}$ speciation from the averaged Saguaro National Park and Saguaro West IMPROVE sites. Six major groupings comprising the $\mathrm{PM}_{2.5}$ mass are shown: FS (fine soil), OA (organic aerosol), EC (elemental carbon), AS (ammonium sulfate), AN (ammonium nitrate) and SS (sea salt).

tween 56 and $1945 \mathrm{~cm}^{-3}$ and winter variability far exceeds that of any other season.

Fine-mode aerosol composition may help to explain the seasonal patterns in $\mathrm{CCN}$ and are illustrated using the IMPROVE data (Fig. 2). Data are presented as an average of the two sites to the east and west of Tucson and can be interpreted as a suburban/semi-rural background reflecting regional-scale aerosol composition onto which local urban sources are superimposed. Aerosol loading is highest during the pre-monsoon season, mainly due to the combined increase in the fine soil fraction, from windblown dust which occurs mainly in the spring and pre-monsoon seasons, and from the increase in sulfate during the premonsoon and monsoon (Sorooshian et al., 2013). Regional wildfire emissions are also most significant during the premonsoon (Sorooshian et al., 2013). While dust particles may themselves act as $\mathrm{CCN}$, they can also enhance the removal of $\mathrm{CN}$ and $\mathrm{CCN}$ by coalescence, while contributions from regional wildfire smoke may periodically enhance $\mathrm{CN}$ and $\mathrm{CCN}$ concentrations. Nitrate is more abundant in winter $(\sim 14 \%)$ compared to other seasons and may be a factor in the observed winter maximum in $\mathrm{CCN}$ concentrations. Sea salt contributes a modest fraction $(\sim 4.5 \%)$ of pre-monsoon aerosol when mid-tropospheric air originates mainly from the subtropical Pacific. The sum of the constituents presented in Fig. 2 constitute between 93 and $101 \%$ of the seasonal average $\mathrm{PM}_{2.5}$, as reported by gravimetric analysis.

The strong influence of urban sources on the fine-mode carbonaceous aerosol in central Tucson is demonstrated by the elevated seasonal mean OC and EC mass concentrations at TACO versus the IMPROVE data (Table 2). This result is consistent with comparisons made by Sorooshian et
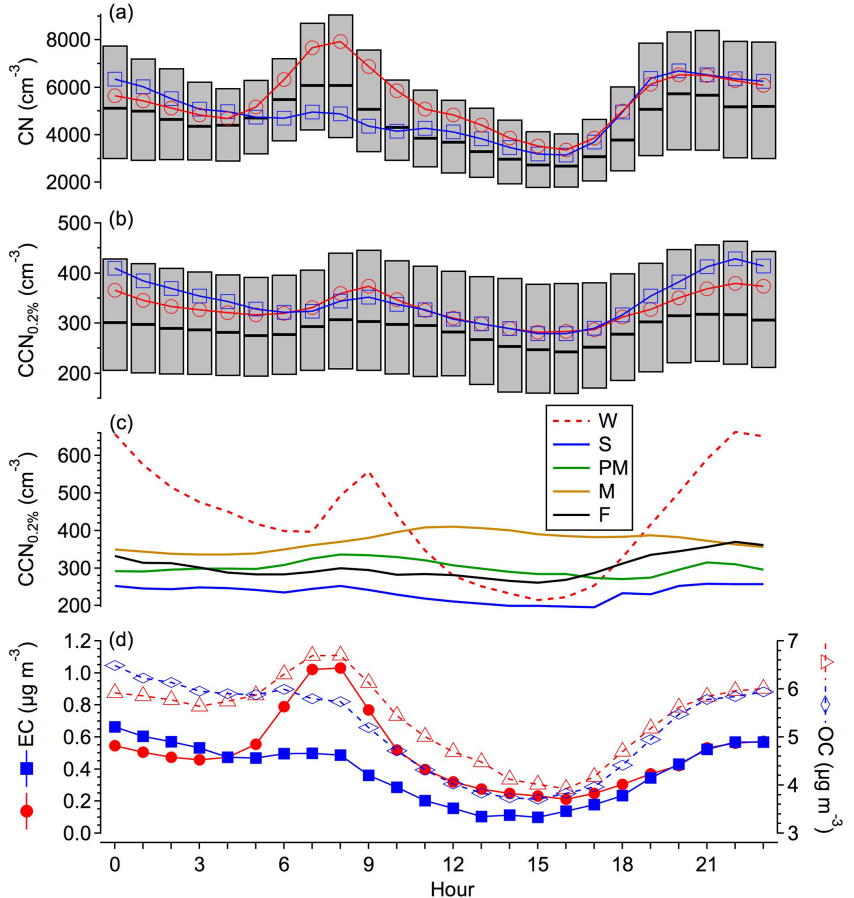

Figure 3. Hourly trends of (a) $\mathrm{CN}$ and (b) $\mathrm{CCN}(0.2 \%)$. Bars indicate median and interquartile range of the variability within each hour. Mean CN and CCN concentrations are shown for both weekdays (red) and weekends (blue). Hourly trends of $\mathrm{CCN}$ are shown in (c) for each season. Mean EC (solid) and OC (dashed) concentrations (d) are shown for weekdays (red) and weekends (blue).

al. (2011) for urban and rural sites in Arizona, which showed that carbonaceous mass concentrations varied strongly between urban and rural sites, whereas sulfate was more regionally homogenous.

\subsection{Diurnal and weekly cycles}

The diurnal cycle of $\mathrm{CN}$ illustrates a clear pattern involving a complex interaction of sources and sinks (Fig. 3a). During weekdays, early mornings (07:00 to 09:00) are characterized by traffic emissions, which increase the $\mathrm{CN}$ and $\mathrm{EC}$ concentrations (Fig. 3d) indicative of fresh fossil combustion aerosol. Mean CN concentrations at 08:00 on weekdays $\left(7925 \mathrm{~cm}^{-3}\right)$ are more than $160 \%$ of the equivalent weekend concentrations $\left(4887 \mathrm{~cm}^{-3}\right)$. During the late morning, the convective boundary layer develops and dilutes the surface layer with relatively clean air from the free troposphere and/or residual layer leading to a marked drop in EC, OC (Fig. 3d) and CN. Through the middle of the day, the convective boundary layer is still growing; however, a subtle reduction in the rate of decrease in CN (12:00 to 14:00) is suggestive of nucleation and growth of new particles which contribute as a source of $\mathrm{CN}$. This is supported by the following: (i) concurrent enhancement in WSOC: OC ratios (Fig. 4c), which can be used as a proxy for secondary organic aerosol 
Table 2. Seasonal mean OC and EC concentrations, and associated standard deviations, at the TACO and IMPROVE sites.

\begin{tabular}{llrrrrr}
\hline Site & $\begin{array}{l}\text { Concentration } \\
\left(\mu \mathrm{g} \mathrm{m}^{-3}\right)\end{array}$ & $\mathrm{W}$ & $\mathrm{S}$ & $\mathrm{PM}$ & $\mathrm{M}$ & $\mathrm{F}$ \\
& $\mathrm{EC}$ & $0.69 \pm 0.66$ & $0.38 \pm 0.38$ & $0.27 \pm 0.36$ & $0.40 \pm 0.34$ & $0.54 \pm 0.46$ \\
\multirow{2}{*}{ TACO } & OC & $6.96 \pm 3.40$ & $5.05 \pm 2.25$ & $4.87 \pm 1.98$ & $4.40 \pm 1.60$ & $5.31 \pm 2.20$ \\
\hline \multirow{2}{*}{ SAGUARO NM } & EC & $0.15 \pm 0.07$ & $0.11 \pm 0.05$ & $0.10 \pm 0.05$ & $0.12 \pm 0.04$ & $0.13 \pm 0.07$ \\
& OC & $0.51 \pm 0.18$ & $0.50 \pm 0.17$ & $0.63 \pm 0.33$ & $0.63 \pm 0.27$ & $0.45 \pm 0.20$ \\
\hline \multirow{2}{*}{ SAGUARO WEST } & EC & $0.22 \pm 0.13$ & $0.12 \pm 0.06$ & $0.11 \pm 0.05$ & $0.13 \pm 0.04$ & $0.18 \pm 0.08$ \\
& OC & $0.61 \pm 0.30$ & $0.49 \pm 0.17$ & $0.74 \pm 0.32$ & $0.69 \pm 0.28$ & $0.55 \pm 0.20$ \\
\hline
\end{tabular}

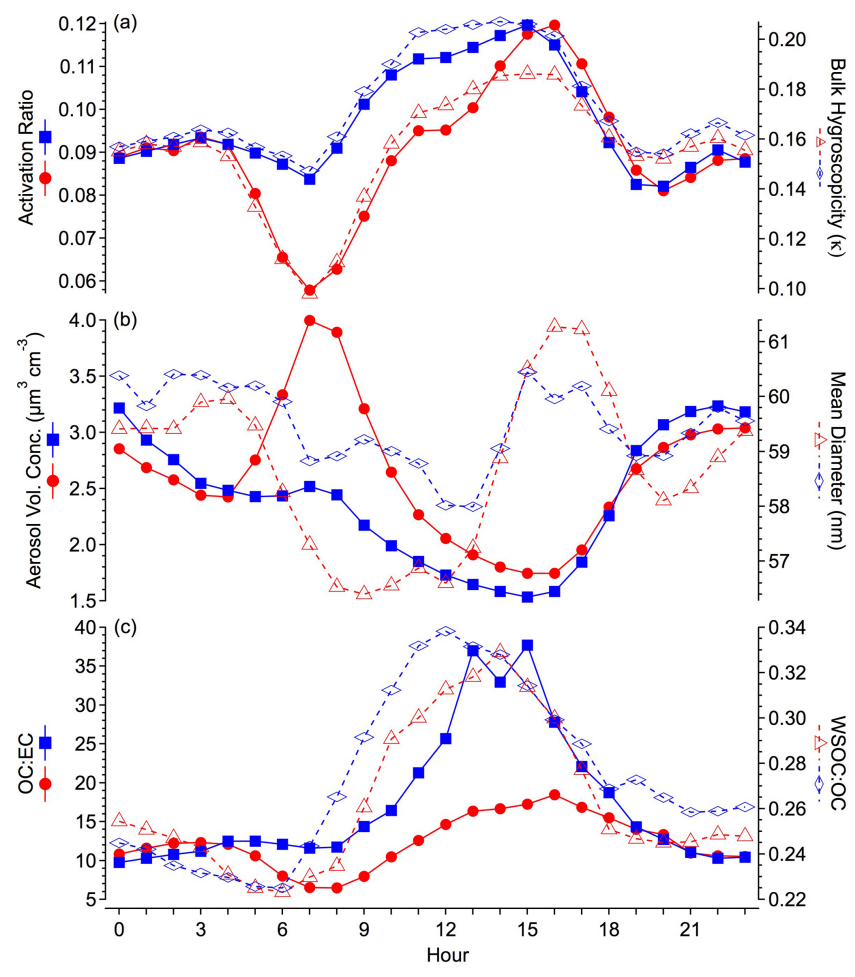

Figure 4. Hourly trends of activation-related properties, OC : EC ratio, and WSOC: OC ratio for weekdays (red) and weekends (blue). Note the applicability of the OC : EC ratio starts to become less well defined on weekends above 25 , since EC concentrations are typically below limit of detection (LOD).

(SOA) away from biomass-burning sources (Miyazaki et al., 2006; Kondo et al., 2007; Weber et al., 2007); (ii) increasing $\mathrm{OC}$ : EC ratios (Fig. 4c) and (iii) a second dip in the mean aerosol diameter (Fig. 4b). The latter two results are particularly clear on weekends when the morning traffic signature is suppressed.

By mid-afternoon (14:00 to 16:00), the convective boundary layer reaches its peak depth and photochemical processes begin to slow down, leaving transport (vertical and horizontal) and coagulation as the dominant mechanisms, producing a net reduction in $\mathrm{CN}$ concentrations (Fig. 3a) and increase in mean diameter (Fig. 4b) while integrated aerosol volume concentration (used as a proxy for relative trends in $\mathrm{PM}_{1}$ ) remains flat (Fig. 4b). By late afternoon (16:00 to 18:00) the convective boundary layer decouples from the surface and aerosol number and mass concentrations build again in the surface layer due to the evening peak in traffic emissions, with accompanying increases in EC and OC and reductions in mean diameter. During this time, secondary aerosol may still be influential once the boundary layer is decoupled, since residual ozone concentrations near the surface may still be sufficient to drive SOA production in the now thin surface layer.

The annualized diurnal cycle of CCN (Fig. 3b) is less pronounced than that of $\mathrm{CN}$ mainly since $\mathrm{CCN}$ are typically unaffected by contributions from ultrafine particles with diameters less than $50 \mathrm{~nm}$, which are highly variable. There is an increase in $\mathrm{CCN}$ during the evening, reaching a daily maximum at 22:00 and, interestingly, concentrations on weekends $\left(429 \mathrm{~cm}^{-3}\right)$ are higher than on weekdays $\left(380 \mathrm{~cm}^{-3}\right)$. There is a large range of $\mathrm{CCN}$ variability observed within each hour when compared to the hourly composite mean trend which is partially explained by the seasonal differences in the CCN diurnal cycle (Fig. 3c). During winter, there is a significant diurnal cycle in $\mathrm{CCN}$, while in other seasons the diurnal pattern is relatively flat. Due to reduced winter temperatures, semi-volatile organics are more likely to partition to the particle phase, which may incrementally shift the size distribution of freshly emitted particles associated with morning traffic towards larger sizes. In addition, nitrate also forms a larger component of the regional aerosol than in other seasons, which helps to increase the hygroscopicity and to reduce the diameter required for droplet activation. Both factors likely work in tandem with the diurnal emissions cycle, which results in a CCN pattern which more closely follows $\mathrm{CN}$ than other seasons. The other notable feature is that the peak $\mathrm{CCN}$ concentration occurs during the night in winter while it occurs during the afternoon in summer. In addition to partitioning of semi-volatiles, emissions from domestic wood burning are another potential contributor to $\mathrm{CCN}$ in the winter, while in summer it is likely SOA production, driven 
by photochemistry and moisture during the day (Youn et al., 2013).

A bulk hygroscopicity parameter $(\kappa)$ is derived using the method of Petters and Kreidenweis (2007) and by assuming total activation above a critical activation diameter, such that the $\mathrm{CCN}$ concentration exactly matches the concentration of particles exceeding this critical diameter (Furutani et al., 2008; Burkart et al., 2011; Wonaschütz et al., 2013). Hygroscopicity decreases concurrently with the morning traffic signature (Fig. 4a) and then rebounds through the day to produce a peak between 14:00 and 16:00 matching expectations of organic aging and condensational growth by photochemically oxidized organics and sulfate. As expected, the morning minimum is less extreme on weekends $(\kappa=0.15)$ compared to weekdays $(\kappa=0.10)$ due to reduced traffic and this trend remains through the day with weekend maxima $(\kappa=0.21)$ exceeding weekday values $(\kappa=0.19)$. During the evening and night, the offset is far smaller $(\Delta \kappa \approx 0.005)$. The $\kappa$ parameter tracks the diurnal pattern of activation ratio (Fig. 4a), defined as the ratio of $\mathrm{CCN}$ to $\mathrm{CN}$, which on first glance, together with the rather modest changes in mean aerosol diameter (Fig. 4b), would indicate that chemical composition is driving the $\mathrm{CCN}$ variability at least on diurnal scales. However, two corollaries should be highlighted: (a) the mean aerosol diameter is a rather simplistic representation of changes in the size distribution, and (b) as mentioned earlier, the majority of the $\mathrm{CCN}$ variability is not described by composite mean hourly trends, at least in an annual sense, and thus, as will be examined in the forthcoming section, a more rigorous treatment of the size distribution is needed to better explain overall CCN variability.

\section{Size distribution}

Several studies (e.g., Conant et al., 2004; Dusek et al., 2006; Ervens et al., 2007) have suggested that the size distribution alone can explain $\mathrm{CCN}$ variability; however there are other examples (e.g., Hudson, 2007; Burkart et al., 2011), which refute this, particularly in cases where the aerosol is externally mixed. If the physical and chemical processes which govern size and composition changes are intrinsically tied to a single governing mechanism, a parameterization involving one component may suitably capture the variability in the other, at least when considering a fixed supersaturation. Furutani et al. (2008) reported the activation diameter to be well correlated with activation ratio during a shipborne study in the eastern North Pacific, suggesting compositional changes as a result of aging (where size also increases) to be the major driver for CCN variability. In contrast, Burkart et al. (2011) examined the same relationship but found poor correlation between activation ratio and activation diameter in Vienna, Austria, suggesting a more complex relationship between size and composition.
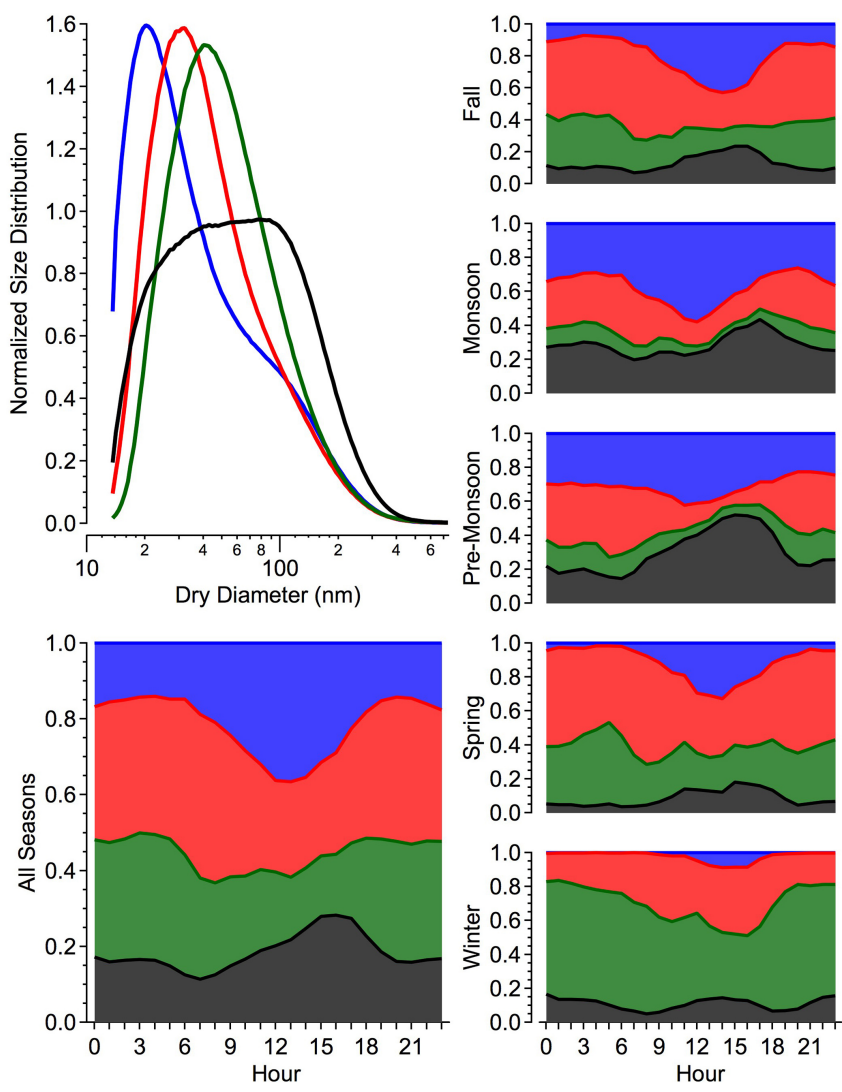

Figure 5. Size distribution cluster centroids, as derived by the " $K$ means" algorithm, and the hourly distribution of cluster associations, separated by season. Clusters are assigned the following identifiers: nucleation (N; blue), fresh fossil (FF; red), winter/nocturnal (WN; green) and condensation/coagulation (CC; black).

The shape of the size distribution can be used to interpret physical processes (e.g., condensation, evaporation, nucleation, coagulation), while relative changes in $\mathrm{CN}$ concentration, combined with changes in shape, offer insight into atmospheric processes (e.g., advection and diffusion) and emissions. The well-established " $K$-means" clustering algorithm (Hartigan and Wong, 1979; Lloyd, 1982) was used here as a statistical tool to group size distributions by shape. The method was implemented with four clusters and the resulting four cluster centroids denoted archetypal size distribution shapes (Fig. 5), to which the observations were assigned, according to their degree of association. The selection of four clusters struck a balance between capturing the salient patterns, while maintaining simplicity; however, we do not claim that this choice was optimal for all applications. Cluster associations were "fuzzy", and therefore an observation could be partially assigned to multiple clusters to reflect the continuity of transitions between clusters in the data set. This provides the added advantage that smooth transitions in cluster properties can be represented without the additional complexity of defining intermediate clusters. A full description of 
Table 3. Seasonally derived mean cluster properties and associated environmental conditions (AR is activation ratio). Meteorological variables ( $T, \mathrm{RH}$ and direct normal irradiance, DNI) are presented as anomalies, based on departure from hourly means for each month. Entries in parentheses indicate that the cluster occurs less than $15 \%$ of the time in that season. An asterisk $(*)$ next to EC denotes a case when the concentration is below LOD. $\mathrm{O}_{3}$ data are obtained from a surface pollutant monitoring site ( $\sim 9 \mathrm{~km}$ from TACO) operated by the Pima County Department of Environmental Quality (Children's Park station).

\begin{tabular}{|c|c|c|c|c|c|c|c|c|c|c|c|c|}
\hline Cluster & Season & $\begin{array}{r}\mathrm{CN} \\
\mathrm{cm}^{-3}\end{array}$ & $\begin{array}{r}\mathrm{CCN} \\
\mathrm{cm}^{-3}\end{array}$ & $\begin{array}{r}\mathrm{AR} \\
-\end{array}$ & $\begin{array}{l}\kappa \\
-\end{array}$ & $\begin{array}{r}\text { EC } \\
\mu g m^{-3}\end{array}$ & $\begin{array}{r}\mathrm{OC} \\
\mu \mathrm{g} \mathrm{m}^{-3}\end{array}$ & WSOC: OC & $\begin{array}{r}\mathrm{O}_{3} \\
\mathrm{ppb}\end{array}$ & $\begin{array}{r}\Delta T \\
{ }^{\circ} \mathrm{C}\end{array}$ & $\begin{array}{r}\Delta \mathrm{RH} \\
\%\end{array}$ & $\begin{array}{r}\Delta \mathrm{DNI} \\
\mathrm{Wm}^{-2}\end{array}$ \\
\hline \multirow{5}{*}{$\mathrm{N}$} & W & (4007) & (195) & $(0.065)$ & $(0.19)$ & $(0.21)$ & (4.81) & $(0.38)$ & (37) & (2.60) & $(-3.8)$ & (35) \\
\hline & S & (4966) & (228) & $(0.057)$ & $(0.16)$ & $(0.17)^{*}$ & (4.51) & $(0.19)$ & (45) & $(0.97)$ & $(-1.7)$ & (75) \\
\hline & PM & 4328 & 276 & 0.076 & 0.15 & 0.23 & 4.48 & 0.29 & 44 & 0.53 & -0.3 & 23 \\
\hline & M & 5687 & 351 & 0.086 & 0.17 & 0.38 & 4.35 & 0.38 & 36 & 0.44 & -2.6 & 38 \\
\hline & F & 6674 & 249 & 0.067 & 0.17 & 0.33 & 4.35 & 0.20 & 33 & 0.68 & 0.9 & 40 \\
\hline \multirow{5}{*}{ FF } & W & 4985 & 249 & 0.064 & 0.17 & 0.75 & 7.20 & 0.23 & 25 & 0.85 & -1.7 & 4 \\
\hline & S & 5161 & 198 & 0.050 & 0.13 & 0.36 & 5.35 & 0.18 & 32 & -0.30 & -0.8 & -3 \\
\hline & PM & 4935 & 278 & 0.067 & 0.12 & $0.10^{*}$ & 5.32 & 0.20 & 33 & -0.77 & -1.4 & -49 \\
\hline & M & 5536 & 360 & 0.084 & 0.15 & 0.46 & 5.09 & 0.32 & 29 & -0.64 & 1.7 & -41 \\
\hline & F & 7256 & 282 & 0.058 & 0.14 & 0.56 & 5.55 & 0.26 & 19 & -0.16 & -1.2 & -15 \\
\hline \multirow{5}{*}{ WN } & W & 6337 & 490 & 0.093 & 0.19 & 1.79 & 11.0 & 0.18 & 16 & -0.42 & -0.1 & -4 \\
\hline & $\mathrm{S}$ & 4980 & 278 & 0.071 & 0.16 & 0.36 & 5.63 & 0.18 & 29 & -0.25 & 2.0 & -43 \\
\hline & PM & (4042) & (334) & (0.098) & $(0.15)$ & $(0.07)^{*}$ & $(5.09)$ & $(0.20)$ & (35) & $(-0.72)$ & $(0.5)$ & $(-40)$ \\
\hline & M & (4382) & (392) & $(0.106)$ & $(0.16)$ & $(0.40)$ & (5.33) & $(0.34)$ & (29) & $(-0.96)$ & $(5.8)$ & $(-60)$ \\
\hline & $\mathrm{F}$ & 7743 & 363 & 0.080 & 0.16 & 0.62 & 5.94 & 0.33 & 16 & -1.06 & 0.9 & -26 \\
\hline \multirow{5}{*}{$\mathrm{CC}$} & W & (6203) & (811) & $(0.153)$ & $(0.23)$ & $(1.08)$ & (9.15) & $(0.27)$ & (18) & $(-0.39)$ & (5.6) & $(-13)$ \\
\hline & S & (2659) & (267) & $(0.124)$ & $(0.18)$ & $(0.17)^{*}$ & (4.63) & $(0.19)$ & (44) & $(1.30)$ & $(-0.3)$ & $(-21)$ \\
\hline & PM & 2412 & 349 & 0.166 & 0.15 & $0.09^{*}$ & 5.03 & 0.28 & 46 & 0.41 & 1.3 & 17 \\
\hline & $\mathrm{M}$ & 2884 & 414 & 0.173 & 0.17 & 0.27 & 4.43 & 0.37 & 38 & 0.26 & 0.2 & -24 \\
\hline & $\mathrm{F}$ & (3964) & (356) & $(0.145)$ & $(0.20)$ & $(0.33)$ & (4.93) & $(0.27)$ & (30) & (1.48) & $(0.9)$ & $(-25)$ \\
\hline
\end{tabular}

the clustering method and the method by which associations are made is provided in the Supplement. The mean diurnal cycle of cluster associations (Fig. 5) and their mean properties (Table 3) provide a physical description of the clusters and are hereafter given the following identifiers, which are indicative of the physical process or "regime", that is, suggested by the cluster properties: nucleation $(\mathrm{N})$, fresh fossil (FF), winter/nocturnal (WN), and coagulation/condensation (CC).

Winter (W) and summer (PM and M) exhibit substantially different patterns in cluster associations on diurnal scales, while the transition seasons ( $\mathrm{S}$ and $\mathrm{F}$ ) contain features of both winter and summer and are therefore more mixed in terms of the driving mechanisms. During winter (W), large swings in the size distribution shape are uncommon; however, with activation at $0.2 \%$ supersaturation occurring at diameters as low as $100 \mathrm{~nm}$, the growth that accompanies a shift from FF to WN is sufficient to significantly increase the activation ratio. Unlike other seasons, it is likely that the main driver for size distribution changes occurring during winter is the equilibrium partitioning of semi-volatile species between gas and particle phase (e.g., nitrate). An additional contributor may result from the offset in emissions patterns between traffic (day) and domestic wood burning (night).
Anomalously colder or more humid conditions tend to result in larger and more hygroscopic particle distributions and are typically also associated with more stable near-surface conditions, leading to suppressed mixing and higher aerosol loading as seen in the WN CN, EC and OC concentrations (Table 3). In the extreme, the infrequent winter occurrence of the CC cluster is merely an extension of this trend occurring during the coldest winter nights, where average hygroscopicity reaches $\kappa=0.23$ and average $\mathrm{CCN}$ concentrations are $811 \mathrm{~cm}^{-3}$. The fact that number, size and hygroscopicity tend to act in association is perhaps the reason why $\mathrm{CCN}$ variability is highest in winter on both synoptic and diurnal scales.

Conversely, in summer (PM and $\mathrm{M}$ ) the shape of the size distribution is very variable and exhibits large swings between $\mathrm{N}$ and $\mathrm{CC}$ clusters (Fig. 5). After primary emissions associated with the morning traffic peak (FF cluster) have been diluted through boundary-layer mixing, competition between the $\mathrm{N}$ and $\mathrm{CC}$ cluster takes over. Unlike winter, there is no monotonic relationship between meteorology and size. Instead, hotter conditions with higher solar exposure tend to bifurcate the size distribution more between $\mathrm{N}$ and $\mathrm{CC}$ clusters, with cooler and cloudy conditions favoring the retention of the intermediate FF or WN clusters. This suggests that 
the $\mathrm{N}$ and $\mathrm{CC}$ clusters are partially driven by photochemically produced secondary aerosol. Higher temperature and stronger direct normal irradiance (DNI) are likely coupled with higher hydroxyl concentrations, and ozone concentrations are typically $30-40 \%$ higher for $\mathrm{N}$ and CC clusters (Table 3 ), which accelerates the production of reduced volatility oxidized organic vapors from precursor volatile organic compounds (VOCs). The partitioning of these vapors between condensation on existing particles and nucleation of new particles is likely a function of the aerosol surface area and the production rate of the low-volatility organics. Anomalously dry conditions are a feature of the $\mathrm{N}$ cluster, suggestive of reduced aerosol water, reducing the available surface area. Another possible mechanism affecting the $\mathrm{N}$ cluster during the summer (PM and $\mathrm{M}$ ) is the evaporation, or lack of condensation, of semi-volatile organic compounds associated with traffic emissions (Robinson et al., 2007) such that the FF cluster takes on some of the features of the $\mathrm{N}$ cluster. This mechanism would be supported by the anomalous contribution of EC to the N cluster during the PM and M seasons. Further analysis of the aerosol and gas-phase composition is needed, before and during the monsoon, in order to fully understand the balance of regional and local processes in driving the preference of $\mathrm{N}$ and $\mathrm{CC}$ clusters.

Tucson is often under the influence of very light mean surface winds and so during the day, the predominant mechanism for ventilation of urban aerosol is through vertical mixing of the convective boundary layer, which is supported by measurements at a nearby mountain site (Shaw, 2007). Furthermore, the climatological mesoscale surface wind pattern, particularly in summer, is light southeasterly winds during the night and morning, followed by northwesterlies in the afternoon and evening, induced by regional topography (Philippin and Betterton, 1997). It is therefore possible for urban aerosol particles and precursor gases to be recycled over the site during the course of the day, through both these mechanisms. Processes which control the cluster associations may be also dependent on regional (e.g., nucleation of biogenic SOA) as well as local effects (e.g., recycling of urban emissions), which happened at an earlier time. The complex influences of this "memory effect", together with the interaction of meteorology and emissions, may be one of the contributing factors which cause evening and overnight $\mathrm{CCN}$ concentrations to be higher on weekends (Fig. 3b).

\section{CCN closure}

Studies aimed at achieving a predictive model of CCN concentrations from measured number, size and composition (i.e., $\mathrm{CCN}$ closure) have shown mixed ability to predict $\mathrm{CCN}$ concentrations across a range of aerosol scenarios. To examine these dependencies, in the context of the present study, we consider the effect that simplifying assumptions have on the ability to predict CCN. Traditionally, closure studies aim to predict the hygroscopic properties from measured composition or subsaturated growth factors, which are then combined with size distribution measurements to predict $\mathrm{CCN}$ (e.g., Ervens et al., 2010). With this method, the intercomparison of various scenarios, and the resulting degree to which CCN concentrations are predicted, is affected by both the model assumptions and the accuracy by which aerosol physicochemical properties are measured. Our focus here is to study the degree of $\mathrm{CCN}$ variability explained by incremental simplifications in a predictive model considered across a range of timescales. One major simplification is the limitation of the treatment of hygroscopicity to a bulk measurement, which is permitted to vary temporally but does not isolate size-dependent changes in hygroscopicity nor the hygroscopicity distribution, which may be an important component in relation to external mixing. These aspects are beyond the scope of these parameterizations and are likely to contribute to model shortfalls. Forthcoming work will separately study the degree of correspondence of hygroscopicity between the sub- and supersaturated regimes, size-dependent hygroscopicity and composition, and the closure of hygroscopicity from composition measurements.

Seven, highly simplified, predictive models are used to estimate CCN over the entire study period: (i) constant CCN (baseline); (ii) constant activation ratio (assesses the effect of number only); (iii) constant hygroscopicity (effect of number and size distribution); (iv) constant size distribution (effect of number and hygroscopicity); (v) measured number with size distribution shape and hygroscopicity, derived from cluster associations; (vi) measured size and number with clusterderived hygroscopicity and (vii) all parameters (a reconstruction, for reference only). The inclusion of models (v) and (vi) assesses whether the predictive skill can be improved by the use of a reduced-order representation of the size distribution and hygroscopicity parameter $(\kappa)$. Models (v) and (vi) can be considered an incremental refinement to models (ii) and (iii) where the assumption is that there is prior knowledge of expected cluster properties and associations.

Predicted CCN concentrations are compared to those measured and two performance metrics are evaluated: (i) "percentage variance explained" (VE) metric, which is the variance in the measured CCN explained by the model as determined by mean square residuals; and (ii) a "normalized mean error" (NME) metric, defined as the root mean square residual between modeled and measured $\mathrm{CCN}$ concentrations expressed as a percentage of the mean measured $\mathrm{CCN}$ concentration for the epoch. While both these metrics are connected, the VE is a better descriptor of the specific performance of the model, whereas the NME puts the model in the context of overall predictability. Models are first tested using (i) the cumulative data set and (ii) for the five predefined seasons with model parameters set using seasonal best-fit values. The models (except $\mathrm{v}$ and vi) are then tested, using the same methodology, on data that have been filtered using a $24 \mathrm{~h}$ running average and 7-day average, with the underly- 
Table 4. Closure model performance as quantified by variance explained (top) and normalized mean error (bottom). Models (i)-(iv) include holding constant either CCN, activation ratio (AR), $\kappa$, or size distribution (SD). Model (v) uses the cluster properties and associations (see Fig. 5 and Table 3), model (vi) uses the same assumptions as model (iii) except that $\kappa$ is determined from cluster associations, and model (vii) is a reconstruction for reference only. A dash (-) indicates that the result is not available or performed so poorly it cannot be quantified by the metric.

\begin{tabular}{|c|c|c|c|c|c|c|c|c|}
\hline & & \multicolumn{7}{|c|}{ Model (\%VE) } \\
\hline & & (i) & (ii) & (iii) & (iv) & (v) & (vi) & (vii) \\
\hline & & Const. CCN & Const. AR & Const. $\kappa$ & Const. SD & Clus. only & Clus. $\kappa$ & Ref. \\
\hline \multirow{6}{*}{ All } & ALL & - & 3.7 & 63.2 & 43.9 & 62.3 & 68.4 & 99.6 \\
\hline & $\mathrm{W}$ & - & 44.9 & 81.6 & 72.5 & 78.4 & 84.1 & 99.7 \\
\hline & $S$ & - & - & 25.3 & 55.3 & 3.5 & 37.5 & 99.7 \\
\hline & PM & - & - & 40.5 & - & 43.1 & 34.2 & 99.4 \\
\hline & M & - & - & 35.5 & - & - & 42.3 & 99.1 \\
\hline & $\mathrm{F}$ & - & - & 40.3 & 31.1 & 3.4 & 54.6 & 99.4 \\
\hline \multirow{6}{*}{ Daily } & ALL & - & 6.1 & 70.0 & 47.0 & - & - & 99.4 \\
\hline & $\mathrm{W}$ & - & 35.9 & 81.2 & 71.6 & - & - & 99.5 \\
\hline & S & - & 6.5 & - & 62.1 & - & - & 99.0 \\
\hline & PM & - & 0.2 & 52.5 & 15.4 & - & - & 98.7 \\
\hline & M & - & - & 64.0 & - & - & - & 98.5 \\
\hline & $\mathrm{F}$ & - & - & 59.9 & 17.8 & - & - & 98.1 \\
\hline \multirow{9}{*}{ Weekly } & ALL & - & 7.1 & 67.7 & 43.3 & - & - & 99.0 \\
\hline & $\mathrm{W}$ & - & 15.8 & 66.4 & 77.8 & - & - & 98.8 \\
\hline & $\mathrm{S}$ & - & 6.0 & 33.7 & 74.1 & - & - & 98.3 \\
\hline & $\mathrm{PM}$ & - & 45.4 & 72.9 & 75.8 & - & - & 96.9 \\
\hline & $\mathrm{M}$ & - & - & 43.9 & - & - & - & 96.3 \\
\hline & $\mathrm{F}$ & - & 3.9 & 89.5 & 0.3 & - & - & 97.9 \\
\hline & & \multicolumn{7}{|c|}{ Model (\%NME) } \\
\hline & & (i) & (ii) & (iii) & (iv) & $(\mathrm{v})$ & (vi) & (vii) \\
\hline & & Const. CCN & Const. AR & Const. $\kappa$ & Const. SD & Clus. only & Clus. $\kappa$ & Ref. \\
\hline \multirow{6}{*}{ All } & ALL & 73 & 72 & 45 & 55 & 45 & 41 & 4.4 \\
\hline & $\mathrm{W}$ & 94 & 70 & 40 & 49 & 44 & 38 & 5.2 \\
\hline & $\mathrm{S}$ & 70 & 73 & 60 & 47 & 69 & 55 & 4.0 \\
\hline & $\mathrm{PM}$ & 46 & 59 & 36 & 53 & 35 & 38 & 3.7 \\
\hline & M & 34 & 58 & 27 & 58 & 36 & 26 & 3.3 \\
\hline & $\mathrm{F}$ & 53 & 60 & 41 & 44 & 52 & 36 & 4.0 \\
\hline \multirow{6}{*}{ Daily } & ALL & 53 & 52 & 29 & 40 & - & - & 4.2 \\
\hline & $\mathrm{W}$ & 63 & 51 & 27 & 34 & - & - & 4.6 \\
\hline & $\mathrm{S}$ & 48 & 47 & 60 & 30 & - & - & 4.7 \\
\hline & PM & 33 & 32 & 22 & 30 & - & - & 3.7 \\
\hline & $\mathrm{M}$ & 26 & 37 & 16 & 37 & - & - & 3.2 \\
\hline & $\mathrm{F}$ & 31 & 34 & 20 & 28 & - & - & 4.2 \\
\hline \multirow{6}{*}{ Weekly } & ALL & 36 & 35 & 20 & 27 & - & - & 3.6 \\
\hline & $\mathrm{W}$ & 36 & 33 & 21 & 17 & - & - & 4.0 \\
\hline & $\mathrm{S}$ & 27 & 26 & 22 & 14 & - & - & 3.5 \\
\hline & PM & 22 & 16 & 11 & 11 & - & - & 3.8 \\
\hline & $\mathrm{M}$ & 16 & 20 & 12 & 25 & - & - & 3.1 \\
\hline & $\mathrm{F}$ & 21 & 21 & 6.8 & 21 & - & - & 3.1 \\
\hline
\end{tabular}

ing motivation to determine if environmental factors which control CCN predictability differ between diurnally and synoptically driven timescales.

The results (Table 4) show that when all seasons are considered, a constant hygroscopicity assumption explains more of the measured variance $(\sim 63 \% \mathrm{VE})$ than a constant size distribution ( $\sim 44 \%$ VE) suggesting that overall, the size distribution is generally a more important driver for $\mathrm{CCN}$ variability than composition. However, the goodness of fit (VE) is far lower than that presented by Dusek et al. (2006) and is 
probably associated with the complexity of the aerosol mixing state and spatiotemporal variability in composition, due to the proximity of the TACO site to fresh emission sources as compared to the Dusek et al. (2006) study site. To put the TACO results in more context, fresh pollution aerosol in other urban areas such as Riverside and Houston could not be fully represented without knowledge of size-resolved composition (Cubison et al., 2008; Ervens et al., 2010). A number of other studies have shown that mixing state can help improve predictive capability of CCN behavior (Wex et al., 2010), including Atlanta (Padró et al., 2012) and during early morning rush hour near Mexico City (Lance et al., 2013); but studies also report that hydrophobic particles emitted in urban areas quickly ( $\sim$ few hours) become internal mixtures via condensation of secondary hygroscopic species (e.g., Wang et al., 2010; Mei et al., 2013).

In the daily and weekly filtered cases, the relative balance between size and composition is also similar. Using the submicron number concentration as a predictive model for $\mathrm{CCN}$ (i.e., a constant activation ratio assumption) performs poorly in all annual cases (and all seasonal cases except winter) since it is strongly affected by variability in nucleation and small Aitken-mode particles from fresh emissions that do not contribute to $\mathrm{CCN}$ at the supersaturation levels considered here.

Compared to other seasons, the simplified predictive models perform the best in winter in terms of VE; however, this season also has far higher variability in $\mathrm{CCN}$ than any other season across the three timescales considered. Winter is also the only season where a constant activation ratio assumption offers any skill in $\mathrm{CCN}$ predictability suggesting that the modulation of $\mathrm{CCN}$ is more tied to bulk aerosol sources and sinks than compositional or size-dependent changes or that these processes are strongly interlinked. Winter aerosol is mainly controlled by an interplay of urban emissions balanced by transport and mixing such that there is a strong correlation between the diurnal cycle of $\mathrm{CN}$ and $\mathrm{EC}$, which serves as a combustion tracer. Strong nocturnal surface inversions, in conjunction with a lack of surface wind-induced mixing, trap urban emissions close to the surface before the convective boundary layer develops, which happens later in the day than other seasons. Intermittent synoptic-scale influences, such as frontal passages, affect aerosol sinks directly through wet scavenging, although this effect is presumably much weaker than less arid regions, and drive regional transport in the lower troposphere, which ventilates the urban plume. Synoptic systems affect column stability, which indirectly affects aerosol loading by regulating the extent of diurnally driven vertical mixing. Chemical aging processes and photochemically driven secondary aerosol formation are suppressed in winter compared to other seasons simplifying the diurnal changes in hygroscopicity and size distribution, although size and hygroscopicity appear to be tied to the diurnal cycle through temperature changes. Both size-simplified (constant $\kappa$, model iii) and hygroscopicity-simplified (con- stant size distribution, model iv) models explain 82 and $73 \%$ of the $\mathrm{CCN}$ variance, respectively, reiterating that size and hygroscopicity changes are strongly coupled. The weekly filtered data indicate that hygroscopicity becomes marginally more influential than size changes over longer timescales and is perhaps a consequence of regional sources associated with long-range transport competing with local emissions.

Regional-scale transport is also an important feature of spring, which is a transition season where mid-latitude meteorology still affects the region, boundary-layer mixing becomes more vigorous and surface winds are strongest on average. Dust loading is highest and temperature changes on diurnal and synoptic scales are also greatest which affects the partitioning of semi-volatile species (e.g., nitrate). The complex mixing state and highly variable aerosol composition makes $\mathrm{CCN}$ prediction difficult as reflected in the poor performance of the simplified models. The modeled predictability indicates that composition is far more important than size during spring and in fact, the daily filtered data suggest that using the size distribution (model iii) to predict $\mathrm{CCN}$ is worse than assuming a constant seasonal average concentration, indicative of complex aerosol mixing states, morphology and scale-dependent mechanisms.

The pre-monsoon summer reveals a steady improvement in the model performance towards longer timescales (i.e., weekly) and the increasing relative importance of hygroscopicity. Intense solar radiation during this season increases the importance of $\mathrm{VOC}$ and $\mathrm{SO}_{2}$ chemistry to form secondary aerosol species. Aerosol number may be strongly influenced by nucleation and therefore knowledge of the size distribution becomes essential on sub-diurnal scales. Over longer timescales, all simplified approximations become reasonable, suggesting a more stable meteorological pattern which is typical of this season: as the jet migrates northward, synoptic steering becomes lighter and the circulation pattern becomes more driven by mesoscale circulations. The increased importance of hygroscopicity on timescales longer than a week is perhaps indicative of the influence of wildfire smoke and intermittent regional dust transport which periodically affect southern Arizona during this season.

The monsoon season exhibits the poorest performance of the simplified models out of all seasons, which is perhaps expected given the very complex meteorological pattern and the interplay between secondary aerosol production at the regional (e.g., biogenic SOA and sulfate) and local scale (e.g., urban SOA). Knowledge of the size distribution is essential since it is highly variable across all scales driven by both meteorological influences, in the form of monsoon thunderstorms, and secondary aerosol processes. Even considering size variability alone does not yield very satisfactory results implying that aerosol composition is very closely tied to changes in size distribution during the monsoon season. However, CCN variability is also lowest of all seasons, while the mean $\mathrm{CCN}$ concentration is relatively high, implying partial cancellation in the effects caused by changes in size, 
number and composition. The consequence is that the NME metric is actually lowest in monsoon when a constant hygroscopicity model is used, which is the opposite of the situation during winter. Fall shows the opposite pattern to spring and pre-monsoon in that hygroscopicity has decreasing influence over longer timescales, and for the weekly filtered case, the constant hygroscopicity model provides a very satisfactory model of CCN variability.

The inclusion of the cluster associations to estimate $\kappa$ (model vi) provides an incremental improvement in the predictive skill $(+3$ to $+15 \%$ additional $\% \mathrm{VE})$ when compared to a seasonally constant $\kappa$ (model iii), with the exception of the pre-monsoon summer season, where a reduction in $\% \mathrm{VE}$ was observed $(\sim-7 \%)$. Annually, the increase was approximately $+5 \%$ on $\%$ VE. The comparison between the clusterderived activation ratio (model $\mathrm{v}$ ) and a constant activation ratio (model ii) was far more significant with an annual increase of $+59 \%$ on $\% \mathrm{VE}$ suggesting that a low-order representation of the size distribution shape, where other data are unavailable (e.g., from remote sensing methods), may offer a worthwhile improvement to the estimation of $\mathrm{CCN}$ concentration.

\section{Conclusions}

This study investigates the respective importance of aerosol number concentration, size distribution and composition in driving $\mathrm{CCN}$ variability in Tucson, Arizona. In doing so, a long-term characterization of the seasonal, weekly and diurnal patterns in aerosol number concentration, size distribution and selected particle speciation has been achieved. Seasonally, the average $\mathrm{CN}$ concentration exhibits a moderate trend towards a minimum during summer, while $\mathrm{CCN}$ concentrations exhibit significant winter and summer peaks. Weekday and weekend $\mathrm{CN}$ concentrations track the respective diurnal weekday and weekend EC and OC mass concentrations, indicating a strong influence of local combustion aerosol, predominantly from vehicle emissions but also, in winter, from domestic biomass burning. Activation ratio and hygroscopicity, as estimated by $\kappa$, track the morning peak in fossil fuel emissions, by concurrently showing a marked reduction, particularly on weekdays. This helps to support the notion that $\mathrm{CCN}$ concentrations are not significantly enhanced by fresh fossil emissions. The effects of local emissions are typically offset by those of boundary layer mixing; however, during the warmer and more photochemically active seasons, secondary aerosol processes become more influential.

During winter, the interplay between chemistry and dynamics is such that increasing size is accompanied by increasing hygroscopicity. This occurs most commonly at night and during anomalously cold periods, when boundary layer mixing is suppressed and aerosol loading is high, thus increasing $\mathrm{CCN}$ concentrations. Conversely, during the day and particularly during anomalously warm and dry periods, there is sufficient convective mixing to dilute the aerosol, evaporate hygroscopic semi-volatile species and generally promote the abundance of smaller particles, reducing $\mathrm{CCN}$ concentrations. The combined result of these effects is to increase the variability in $\mathrm{CCN}$, since each of these contributing factors act together to enhance or suppress $\mathrm{CCN}$ concentrations. The added consequence is that simplified models offer substantial predictive skill for $\mathrm{CCN}$ variability, even though the observed changes in the size distribution are relatively subtle.

The summer is divided by the arrival of the North American monsoon (July-September), which rapidly increases the abundance of moisture compared to the very hot and dry months that precede it (May-June). Secondary production of sulfate and organics becomes more influential during both summer seasons, and photochemically produced aerosol appears to be the mechanism responsible for an afternoon maximum in CCN concentration, compared to a nocturnal maximum in winter. The diurnal cycle of the boundary layer follows a similar pattern to other seasons, except that mixing heights are generally higher and nocturnal surface inversions are less pronounced, especially during the monsoon. While $\mathrm{CN}$ concentrations drop off during the day similar to other seasons, $\mathrm{CCN}$ concentrations remain relatively more stable indicating that condensed SOA and sulfate play a significant role in offsetting the loss in $\mathrm{CCN}$ caused by dilution.

Another important feature of the summer is the bifurcation in the size distribution shape, where the pattern swings back and forth from (i) an abundance of ultrafine particles that are potentially tied to a nucleation event to (ii) a deficiency of Aitken-mode particles, and a growth in the number of particles larger than $100 \mathrm{~nm}$ that are more in line with a background aerosol population. While the meteorological conditions favoring both regimes are similar and likely explained by SOA and sulfate production, the mechanisms responsible for the bifurcation are still unclear. Possible mechanisms include aerosol water uptake, leading to increased aerosol surface area for condensation, which is supported by lower humidity on days when ultrafine particles are present, particularly before the monsoon. During the monsoon, regional biogenic SOA produced as a result of increased vegetation may explain the periodic import of small SOA particles into the urban plume. Finally, the role of the monsoon thunderstorms may also be responsible for erratic changes to the size distribution simply through the sporadic disruption of the local and regional circulation pattern.

The sensitivities of $\mathrm{CCN}$ concentration to changes in aerosol number, size and composition can be well represented in a theoretical framework as described by Köhler theory and its various refinements. However, the extent to which these driving components vary, and the mechanisms through which they interact, is the primary limitation in consolidating parametric representations suitable for predictive models. Achieving satisfactory $\mathrm{CCN}$ closure using measurements of 
chemical composition and size has generally been most successful with background aerosol where substantial changes in composition are dampened by aging processes. However, the results of this study suggest that in certain regimes (e.g., during winter), where composition, size and number concentration have a more deterministic relationship, there are still opportunities for parametric simplifications to be successful even when chemical processes are relatively complex. Since the relationship can be explained by somewhat broad environmental mechanisms not entirely specific to Tucson, similar conclusions can be drawn for other urban areas with comparable geographical and climatological settings.

The methods employed in this study also have implications for studies in other regions, specifically in the use of clustering and reduced models for $\mathrm{CCN}$ closure. While this study has considered model performance with respect to temporal scales of variability at one site, there is an opportunity to extend this methodology to assess spatial patterns across multiple sites, and to include the development of a generalized clustering method that categorizes spatial and temporal variability. The ultimate goal of such an effort would be to estimate the global performance (by areal coverage) of reduced-order $\mathrm{CCN}$ closure approximations, a result which has substantial importance in constraining aerosol-cloud interactions for modeling future climate scenarios. Future work using the TACO data set will focus on the predictability of $\kappa$ using measurements of composition, patterns in the environmental conditions (e.g., emissions, meteorology and other auxiliary measures) and subsaturated aerosol hygroscopicity, with the primary goal being to determine if a singleparameter representation of $\mathrm{CCN}$ activation is suitable for this environment. In addition, we will focus on addressing the factors which control the summertime size distribution bifurcations and the extent to which they are influenced by biogenic and anthropogenic SOA production pathways.

\section{The Supplement related to this article is available online at doi:10.5194/acp-15-6943-2015-supplement.}

Acknowledgements. This research was supported in part by grant 2 P42 ES04940-11 from the National Institute of Environmental Health Sciences (NIEHS) Superfund Research Program, NIH, the University of Arizona Foundation, the Institute of the Environment at the University of Arizona, and the Center for Environmentally Sustainable Mining through TRIF Water Sustainability Program funding. Funding is also acknowledged from NASA grants NNX14AK79H, NNX12AC10G and NNX14AP75G. Glenn Shaw is acknowledged for helpful suggestions during the preparation of the manuscript. We acknowledge the sponsors of the IMPROVE network, the Pima County Department of Environmental Quality, NREL, UCAR and SuomiNet for data used in this study.

Edited by: V.-M. Kerminen

\section{References}

Albrecht, B. A.: Aerosols, cloud microphysics, and fractional cloudiness, Science, 245, 1227-1230, doi:10.1126/science.245.4923.1227, 1989.

Almeida, G. P., Brito, J., Morales, C. A., Andrade, M. F., and Artaxo, P.: Measured and modelled cloud condensation nuclei $(\mathrm{CCN})$ concentration in São Paulo, Brazil: the importance of aerosol size-resolved chemical composition on $\mathrm{CCN}$ concentration prediction, Atmos. Chem. Phys., 14, 7559-7572, doi:10.5194/acp-14-7559-2014, 2014.

Altaratz, O., Koren, I., Reisin, T., Kostinski, A., Feingold, G., Levin, Z., and Yin, Y.: Aerosols' influence on the interplay between condensation, evaporation and rain in warm cumulus cloud, Atmos. Chem. Phys., 8, 15-24, doi:10.5194/acp-8-15-2008, 2008.

Andreae, M. O. and Rosenfeld, D.: Aerosol-cloudprecipitation interactions. Part 1. The nature and sources of cloud-active aerosols, Earth Sci. Rev., 89, 13-41, doi:10.1016/j.earscirev.2008.03.001, 2008.

Andreae, M. O., Rosenfeld, D., Artaxo, P., Costa, A. A., Frank, G. P., Longo, K. M., and Silva-Dias, M. A. F.: Smoking rain clouds over the Amazon, Science, 303, 1337-1342, doi:10.1126/science.1092779, 2004.

Bougiatioti, A., Fountoukis, C., Kalivitis, N., Pandis, S. N., Nenes, A., and Mihalopoulos, N.: Cloud condensation nuclei measurements in the marine boundary layer of the Eastern Mediterranean: $\mathrm{CCN}$ closure and droplet growth kinetics, Atmos. Chem. Phys., 9, 7053-7066, doi:10.5194/acp-9-7053-2009, 2009.

Brechtel, F. J. and Kreidenweis, S. M.: Predicting particle critical supersaturation from hygroscopic growth measurements in the humidified TDMA. Part II: Laboratory and ambient studies, J. Atmos. Sci., 57, 1872-1887, 2000.

Broekhuizen, K., Chang, R.Y.-W., Leaitch, W. R., Li, S.-M., and Abbatt, J. P. D.: Closure between measured and modeled cloud condensation nuclei $(\mathrm{CCN})$ using size-resolved aerosol compositions in downtown Toronto, Atmos. Chem. Phys., 6, 2513-2524, doi:10.5194/acp-6-2513-2006, 2006.

Burkart, J., Steiner, G., Reischl, G., and Hitzenberger, R.: Longterm study of cloud condensation nuclei $(\mathrm{CCN})$ activation of the atmospheric aerosol in Vienna, Atmos. Environ., 45, 5751-5759, doi:10.1016/j.atmosenv.2011.07.022, 2011.

Burkart, J., Hitzenberger, R., Reischl, G., Bauer, H., Leder, K., and Puxbaum, H.: Activation of "synthetic ambient" aerosols - Relation to chemical composition of particles $<100 \mathrm{~nm}$, Atmos. Environ., 54, 583-591, doi:10.1016/j.atmosenv.2012.01.063, 2012.

Chuang, P. Y.: Measurement of the timescale of hygroscopic growth for atmospheric aerosols, J. Geophys. Res., 108, 4282, doi:10.1029/2002jd002757, 2003.

Chuang, P. Y., Collins, D. R., Pawlowska, H., Snider, J. R., Jonsson, H. H., Brenguier, J. L., Flagan, R. C., and Seinfeld, J. H.: CCN measurements during ACE-2 and their relationship to cloud microphysical properties, Tellus B, 52, 843-867, doi:10.1034/j.1600-0889.2000.00018.x, 2000.

Conant, W. C., VanReken, T. M., Rissman, T. A., Varutbangkul, V., Jonsson, H. H., Nenes, A., Jimenez, J. L., Delia, A. E., Bahreini, R., Roberts, G. C., Flagan, R. C., and Seinfeld, J. H.: Aerosolcloud drop concentration closure in warm cumulus, J. Geophys. Res. 109, D13204, doi:10.1029/2003jd004324, 2004.

Covert, D. S. and Heintzenberg, J.: Size Distributions and Chemical-Properties of Aerosol at $\mathrm{Ny}$ Alesund, Sval- 
bard, Atmos. Environ., 27, 2989-2997, doi:10.1016/09601686(93)90331-R, 1993.

Covert, D. S., Gras, J. L., Wiedensohler, A., and Stratmann, F.: Comparison of directly measured $\mathrm{CCN}$ with $\mathrm{CCN}$ modeled from the number-size distribution in the marine boundary layer during ACE 1 at Cape Grim, Tasmania, J. Geophys. Res., 103, 1659716608, doi:10.1029/98jd01093, 1998.

Cubison, M. J., Ervens, B., Feingold, G., Docherty, K. S., Ulbrich, I. M., Shields, L., Prather, K., Hering, S., and Jimenez, J. L.: The influence of chemical composition and mixing state of Los Angeles urban aerosol on CCN number and cloud properties, Atmos. Chem. Phys., 8, 5649-5667, doi:10.5194/acp-8-5649-2008, 2008.

Duong, H. T., Sorooshian, A., Craven, J. S., Hersey, S. P., Metcalf, A. R., Zhang, X. L., Weber, R. J., Jonsson, H., Flagan, R. C., and Seinfeld, J. H.: Water-soluble organic aerosol in the Los Angeles Basin and outflow regions: Airborne and ground measurements during the 2010 CalNex field campaign, J. Geophys. Res., 116, D00V04, doi:10.1029/2011jd016674, 2011.

Dusek, U., Frank, G. P., Hildebrandt, L., Curtius, J., Schneider, J., Walter, S., Chand, D., Drewnick, F., Hings, S., Jung, D., Borrmann, S., and Andreae, M. O.: Size matters more than chemistry for cloud-nucleating ability of aerosol particles, Science, 312, 1375-1378, doi:10.1126/science.1125261, 2006.

Dusek, U., Frank, G. P., Massling, A., Zeromskiene, K., Iinuma, Y., Schmid, O., Helas, G., Hennig, T., Wiedensohler, A., and Andreae, M. O.: Water uptake by biomass burning aerosol at suband supersaturated conditions: closure studies and implications for the role of organics, Atmos. Chem. Phys., 11, 9519-9532, doi:10.5194/acp-11-9519-2011, 2011.

Ervens, B., Cubison, M., Andrews, E., Feingold, G., Ogren, J. A., Jimenez, J. L., DeCarlo, P., and Nenes, A.: Prediction of cloud condensation nucleus number concentration using measurements of aerosol size distributions and composition and light scattering enhancement due to humidity, J. Geophys. Res., 112, D10S32, doi:10.1029/2006jd007426, 2007.

Ervens, B., Cubison, M. J., Andrews, E., Feingold, G., Ogren, J. A., Jimenez, J. L., Quinn, P. K., Bates, T. S., Wang, J., Zhang, Q., Coe, H., Flynn, M., and Allan, J. D.: CCN predictions using simplified assumptions of organic aerosol composition and mixing state: a synthesis from six different locations, Atmos. Chem. Phys., 10, 4795-4807, doi:10.5194/acp-10-4795-2010, 2010.

Feingold, G.: Modeling of the first indirect effect: Analysis of measurement requirements, Geophys. Res. Lett., 30, 1997, doi:10.1029/2003g1017967, 2003.

Feingold, G. and Chuang, P. Y.: Analysis of the influence of filmforming compounds on droplet growth: Implications for cloud microphysical processes and climate, J. Atmos. Sci., 59, 20062018, doi:10.1175/1520-0469(2002)059<2006:Aotiof>2.0.Co;2, 2002.

Feingold, G., Cotton, W. R., Kreidenweis, S. M., and Davis, J. T.: The impact of giant cloud condensation nuclei on drizzle formation in stratocumulus: Implications for cloud radiative properties, J. Atmos. Sci., 56, 4100-4117, doi:10.1175/15200469(1999)056<4100:Tiogcc>2.0.Co;2, 1999.

Furutani, H., Dall'osto, M., Roberts, G. C., and Prather, K. A.: Assessment of the relative importance of atmospheric aging on $\mathrm{CCN}$ activity derived from field observations, Atmos. Environ., 42, 3130-3142, doi:10.1016/j.atmosenv.2007.09.024, 2008.
Hartigan, J. A. and Wong, M. A.: A K-means clustering algorithm, J. R. Stat. Soc. Ser. C-App., 28, 100-108, 1979.

Hersey, S. P., Craven, J. S., Metcalf, A. R., Lin, J., Lathem, T., Suski, K. J., Cahill, J. F., Duong, H. T., Sorooshian, A., Jonsson, H. H., Shiraiwa, M., Zuend, A., Nenes, A., Prather, K. A., Flagan, R. C., and Seinfeld, J. H.: Composition and hygroscopicity of the Los Angeles Aerosol: CalNex, J. Geophys. Res., 118, 30163036, doi:10.1002/Jgrd.50307, 2013.

Hudson, J. G.: Variability of the relationship between particle size and cloud-nucleating ability, Geophys. Res. Lett., 34, L08801, doi:10.1029/2006gl028850, 2007.

IPCC: Summary for Policymakers, in: Climate Change 2013: The Physical Science Basis. Contribution of Working Group I to the Fifth Assessment Report of the Intergovernmental Panel on Climate Change, edoted by: Stocker, T. F., Qin, D., Plattner, G.-K., Tignor, M., Allen, S. K., Boschung, J., Nauels, A., Xia, Y., Bex, V., and Midgley, P. M., Cambridge University Press, Cambridge, UK and New York, NY, USA, 2013.

Jurányi, Z., Gysel, M., Weingartner, E., DeCarlo, P. F., Kammermann, L., and Baltensperger, U.: Measured and modelled cloud condensation nuclei number concentration at the high alpine site Jungfraujoch, Atmos. Chem. Phys., 10, 7891-7906, doi:10.5194/acp-10-7891-2010, 2010.

Jurányi, Z., Gysel, M., Weingartner, E., Bukowiecki, N., Kammermann, L., and Baltensperger, U.: A 17 month climatology of the cloud condensation nuclei number concentration at the high alpine site Jungfraujoch, J. Geophys. Res., 116, D10204, doi:10.1029/2010jd015199, 2011.

Köhler, H.: The nucleus in and the growth of hygroscopic droplets., T. Faraday Soc., 32, 1152-1161, doi:10.1039/Tf9363201152, 1936.

Kondo, Y., Miyazaki, Y., Takegawa, N., Miyakawa, T., Weber, R. J., Jimenez, J. L., Zhang, Q., and Worsnop, D. R.: Oxygenated and water-soluble organic aerosols in Tokyo, J. Geophys. Res., 112, D01203, doi:10.1029/2006jd007056, 2007.

Lance, S., Nenes, A., and Rissman, T. A.: Chemical and dynamical effects on cloud droplet number: Implications for estimates of the aerosol indirect effect, J. Geophys. Res., 109, D22208, doi:10.1029/2004jd004596, 2004.

Lance, S., Nenes, A., Mazzoleni, C., Dubey, M. K., Gates, H., Varutbangkul, V., Rissman, T. A., Murphy, S. M., Sorooshian, A., Flagan, R. C., Seinfeld, J. H., Feingold, G., and Jonsson, H. H.: Cloud condensation nuclei activity, closure, and droplet growth kinetics of Houston aerosol during the Gulf of Mexico Atmospheric Composition and Climate Study (GoMACCS), J. Geophys. Res., 114, D00F15, doi:10.1029/2008jd011699, 2009.

Lance, S., Raatikainen, T., Onasch, T. B., Worsnop, D. R., Yu, X.-Y., Alexander, M. L., Stolzenburg, M. R., McMurry, P. H., Smith, J. N., and Nenes, A.: Aerosol mixing state, hygroscopic growth and cloud activation efficiency during MIRAGE 2006, Atmos. Chem. Phys., 13, 5049-5062, doi:10.5194/acp-13-5049-2013, 2013.

Lathem, T. L., Beyersdorf, A. J., Thornhill, K. L., Winstead, E. L., Cubison, M. J., Hecobian, A., Jimenez, J. L., Weber, R. J., Anderson, B. E., and Nenes, A.: Analysis of CCN activity of Arctic aerosol and Canadian biomass burning during summer 2008, Atmos. Chem. Phys., 13, 2735-2756, doi:10.5194/acp-13-27352013, 2013.

Levin, E. J. T., Prenni, A. J., Petters, M. D., Kreidenweis, S. M., Sullivan, R. C., Atwood, S. A., Ortega, J., DeMott, P. J., and Smith, 
J. N.: An annual cycle of size-resolved aerosol hygroscopicity at a forested site in Colorado, J. Geophys. Res., 117, D06201, doi:10.1029/2011jd016854, 2012.

Lim, H. J., Carlton, A. G., and Turpin, B. J.: Isoprene forms secondary organic aerosol through cloud processing: Model simulations, Environ. Sci. Technol., 39, 4441-4446, doi:10.1021/Es048039h, 2005.

Lloyd, S. P.: Least-Squares Quantization in PCM, IEEE T. Inform. Theory, 28, 129-137, doi:10.1109/Tit.1982.1056489, 1982.

Malm, W. C., Sisler, J. F., Huffman, D., Eldred, R. A., and Cahill, T. A.: Spatial and Seasonal Trends in Particle Concentration and Optical Extinction in the United States, J. Geophys. Res., 99, 1347-1370, doi:10.1029/93jd02916, 1994.

Martin, M., Chang, R. Y.-W., Sierau, B., Sjogren, S., Swietlicki, E., Abbatt, J. P. D., Leck, C., and Lohmann, U.: Cloud condensation nuclei closure study on summer arctic aerosol, Atmos. Chem. Phys., 11, 11335-11350, doi:10.5194/acp-11-11335-2011, 2011.

McFiggans, G., Artaxo, P., Baltensperger, U., Coe, H., Facchini, M. C., Feingold, G., Fuzzi, S., Gysel, M., Laaksonen, A., Lohmann, U., Mentel, T. F., Murphy, D. M., O’Dowd, C. D., Snider, J. R., and Weingartner, E.: The effect of physical and chemical aerosol properties on warm cloud droplet activation, Atmos. Chem. Phys., 6, 2593-2649, doi:10.5194/acp-6-2593-2006, 2006.

Mei, F., Setyan, A., Zhang, Q., and Wang, J.: CCN activity of organic aerosols observed downwind of urban emissions during CARES, Atmos. Chem. Phys., 13, 12155-12169, doi:10.5194/acp-13-12155-2013, 2013.

Miyazaki, Y., Kondo, Y., Takegawa, N., Komazaki, Y., Fukuda, M., Kawamura, K., Mochida, M., Okuzawa, K., and Weber, R. J.: Time-resolved measurements of water-soluble organic carbon in Tokyo, J. Geophys. Res., 111, D23206, doi:10.1029/2006jd007125, 2006.

Moore, R. H., Cerully, K., Bahreini, R., Brock, C. A., Middlebrook, A. M., and Nenes, A.: Hygroscopicity and composition of California CCN during summer 2010, J. Geophys. Res., 117, D00V12, doi:10.1029/2011jd017352, 2012.

Nenes, A., Charlson, R. J., Facchini, M. C., Kulmala, M., Laaksonen, A., and Seinfeld, J. H.: Can chemical effects on cloud droplet number rival the first indirect effect?, Geophys. Res. Lett., 29, 1848, doi:10.1029/2002g1015295, 2002.

Padró, L. T., Moore, R. H., Zhang, X., Rastogi, N., Weber, R. J., and Nenes, A.: Mixing state and compositional effects on $\mathrm{CCN}$ activity and droplet growth kinetics of size-resolved CCN in an urban environment, Atmos. Chem. Phys., 12, 10239-10255, doi:10.5194/acp-12-10239-2012, 2012.

Partridge, D. G., Vrugt, J. A., Tunved, P., Ekman, A. M. L., Struthers, H., and Sorooshian, A.: Inverse modelling of cloudaerosol interactions - Part 2: Sensitivity tests on liquid phase clouds using a Markov chain Monte Carlo based simulation approach, Atmos. Chem. Phys., 12, 2823-2847, doi:10.5194/acp12-2823-2012, 2012.

Petters, M. D. and Kreidenweis, S. M.: A single parameter representation of hygroscopic growth and cloud condensation nucleus activity, Atmos. Chem. Phys., 7, 1961-1971, doi:10.5194/acp-71961-2007, 2007.

Petters, M. D. and Kreidenweis, S. M.: A single parameter representation of hygroscopic growth and cloud condensation nucleus activity - Part 2: Including solubility, Atmos. Chem. Phys., 8, 6273-6279, doi:10.5194/acp-8-6273-2008, 2008.
Philippin, S. and Betterton, E. A.: Cloud condensation nuclei concentrations in southern Arizona: Instrumentation and early observations, Atmos. Res., 43, 263-275, doi:10.1016/S01698095(96)00046-4, 1997.

Pierce, J. R. and Adams, P. J.: Uncertainty in global CCN concentrations from uncertain aerosol nucleation and primary emission rates, Atmos. Chem. Phys., 9, 1339-1356, doi:10.5194/acp-91339-2009, 2009.

Quinn, P. K., Bates, T. S., Coffman, D. J., and Covert, D. S.: Influence of particle size and chemistry on the cloud nucleating properties of aerosols, Atmos. Chem. Phys., 8, 1029-1042, doi:10.5194/acp-8-1029-2008, 2008.

Raymond, T. M. and Pandis, S. N.: Cloud activation of singlecomponent organic aerosol particles, J. Geophys. Res., 107, 4787, doi:10.1029/2002jd002159, 2002.

Raymond, T. M. and Pandis, S. N.: Formation of cloud droplets by multicomponent organic particles, J. Geophys. Res., 108, 4469, doi:10.1029/2003jd003503, 2003.

Riipinen, I., Pierce, J. R., Yli-Juuti, T., Nieminen, T., Häkkinen, S., Ehn, M., Junninen, H., Lehtipalo, K., Petäjä, T., Slowik, J., Chang, R., Shantz, N. C., Abbatt, J., Leaitch, W. R., Kerminen, V.-M., Worsnop, D. R., Pandis, S. N., Donahue, N. M., and Kulmala, M.: Organic condensation: a vital link connecting aerosol formation to cloud condensation nuclei (CCN) concentrations, Atmos. Chem. Phys., 11, 3865-3878, doi:10.5194/acp-11-38652011, 2011.

Rissman, T. A., Nenes, A., and Seinfeld, J. H.: Chemical amplification (or dampening) of the Twomey effect: Conditions derived from droplet activation theory, J. Atmos. Sci., 61, 919930, doi:10.1175/1520-0469(2004)061<0919:Caodot>2.0.Co;2, 2004.

Roberts, G. C. and Nenes, A.: A continuous-flow streamwise thermal-gradient $\mathrm{CCN}$ chamber for atmospheric measurements, Aerosol Sci. Tech., 39, 206-221, doi:10.1080/027868290913988, 2005.

Roberts, G. C., Artaxo, P., Zhou, J. C., Swietlicki, E., and Andreae, M. O.: Sensitivity of CCN spectra on chemical and physical properties of aerosol: A case study from the Amazon Basin, J. Geophys. Res., 107, 8070, doi:10.1029/2001jd000583, 2002.

Robinson, A. L., Donahue, N. M., Shrivastava, M. K., Weitkamp, E. A., Sage, A. M., Grieshop, A. P., Lane, T. E., Pierce, J. R., and Pandis, S. N.: Rethinking organic aerosols: Semivolatile emissions and photochemical aging, Science, 315, 1259-1262, doi:10.1126/science.1133061, 2007.

Rose, D., Gunthe, S. S., Mikhailov, E., Frank, G. P., Dusek, U., Andreae, M. O., and Pöschl, U.: Calibration and measurement uncertainties of a continuous-flow cloud condensation nuclei counter (DMT-CCNC): CCN activation of ammonium sulfate and sodium chloride aerosol particles in theory and experiment, Atmos. Chem. Phys., 8, 1153-1179, doi:10.5194/acp-8-11532008, 2008.

Shaw, G. E.: Aerosols at a mountaintop observatory in Arizona, J. Geophys. Res., 112, D07206, doi:10.1029/2005jd006893, 2007.

Sorooshian, A., Wonaschütz, A., Jarjour, E. G., Hashimoto, B. I., Schichtel, B. A., and Betterton, E. A.: An aerosol climatology for a rapidly growing arid region (southern Arizona): Major aerosol species and remotely sensed aerosol properties, J. Geophys. Res., 116, D19205, doi:10.1029/2011jd016197, 2011. 
Sorooshian, A., Shingler, T., Harpold, A., Feagles, C. W., Meixner, T., and Brooks, P. D.: Aerosol and precipitation chemistry in the southwestern United States: spatiotemporal trends and interrelationships, Atmos. Chem. Phys., 13, 7361-7379, doi:10.5194/acp-13-7361-2013, 2013.

Stevens, B. and Feingold, G.: Untangling aerosol effects on clouds and precipitation in a buffered system, Nature, 461, 607-613, doi:10.1038/Nature08281, 2009.

Sullivan, A. P., Peltier, R. E., Brock, C. A., de Gouw, J. A., Holloway, J. S., Warneke, C., Wollny, A. G., and Weber, R. J.: Airborne measurements of carbonaceous aerosol soluble in water over northeastern United States: Method development and an investigation into water-soluble organic carbon sources, J. Geophys. Res., 111, D23S46, doi:10.1029/2006jd007072, 2006.

Twomey, S.: Influence of Pollution on Shortwave Albedo of Clouds, J. Atmos. Sci., 34, 1149-1152, 1977.

Wang, J., Cubison, M. J., Aiken, A. C., Jimenez, J. L., and Collins, D. R.: The importance of aerosol mixing state and size-resolved composition on $\mathrm{CCN}$ concentration and the variation of the importance with atmospheric aging of aerosols, Atmos. Chem. Phys., 10, 7267-7283, doi:10.5194/acp-10-7267-2010, 2010.

Ware, R. H., Fulker, D. W., Stein, S. A., Anderson, D. N., Avery, S. K., Clark, R. D., Droegemeier, K. K., Kuettner, J. P., Minster, J. B., and Sorooshian, S.: SuomiNet: A real-time national GPS network for atmospheric research and education, B. Am. Meteorol. Soc., 81, 677-694, doi:10.1175/15200477(2000)081<0677:Sarngn>2.3.Co;2, 2000.

Weber, R. J., Sullivan, A. P., Peltier, R. E., Russell, A., Yan, B., Zheng, M., de Gouw, J., Warneke, C., Brock, C., Holloway, J. S., Atlas, E. L., and Edgerton, E.: A study of secondary organic aerosol formation in the anthropogenicinfluenced southeastern United States, J. Geophys. Res., 112, D13302, doi:10.1029/2007jd008408, 2007.
Wex, H., McFiggans, G., Henning, S., and Stratmann, F.: Influence of the external mixing state of atmospheric aerosol on derived CCN number concentrations, Geophys. Res. Lett., 37, L10805, doi:10.1029/2010g1043337, 2010.

Wonaschütz, A., Hersey, S. P., Sorooshian, A., Craven, J. S., Metcalf, A. R., Flagan, R. C., and Seinfeld, J. H.: Impact of a large wildfire on water-soluble organic aerosol in a major urban area: the 2009 Station Fire in Los Angeles County, Atmos. Chem. Phys., 11, 8257-8270, doi:10.5194/acp-11-8257-2011, 2011.

Wonaschütz, A., Coggon, M., Sorooshian, A., Modini, R., Frossard, A. A., Ahlm, L., Mülmenstädt, J., Roberts, G. C., Russell, L. M., Dey, S., Brechtel, F. J., and Seinfeld, J. H.: Hygroscopic properties of smoke-generated organic aerosol particles emitted in the marine atmosphere, Atmos. Chem. Phys., 13, 9819-9835, doi:10.5194/acp-13-9819-2013, 2013.

Wu, Z. J., Poulain, L., Henning, S., Dieckmann, K., Birmili, W., Merkel, M., van Pinxteren, D., Spindler, G., Müller, K., Stratmann, F., Herrmann, H., and Wiedensohler, A.: Relating particle hygroscopicity and $\mathrm{CCN}$ activity to chemical composition during the HCCT-2010 field campaign, Atmos. Chem. Phys., 13, 79837996, doi:10.5194/acp-13-7983-2013, 2013.

Youn, J. S., Wang, Z., Wonaschütz, A., Arellano, A., Betterton, E. A., and Sorooshian, A.: Evidence of aqueous secondary organic aerosol formation from biogenic emissions in the North American Sonoran Desert, Geophys. Res. Lett., 40, 3468-3472, doi:10.1002/Grl.50644, 2013. 